\title{
Maternal exposure to UV filters: associations with maternal thyroid hormones, IGF-I/IGFBP3 and birth outcomes
}

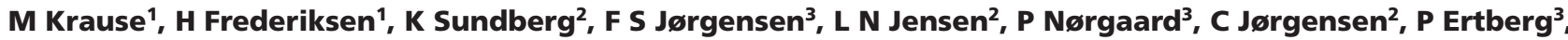 \\ J H Petersen ${ }^{1,4}$, U Feldt-Rasmussen ${ }^{5}$, A Juul ${ }^{1}$, K T Drzewiecki ${ }^{6}$, N E Skakkebaek ${ }^{1}$ and A M Andersson ${ }^{1}$
}

${ }^{1}$ Department of Growth and Reproduction \& International Center for Research and Research Training in Endocrine Disruption of Male Reproduction and Child Health (EDMaRC), Rigshospitalet, University of Copenhagen, Copenhagen, Denmark

${ }^{2}$ Center of Fetal Medicine and Pregnancy, Department of Obstetrics, Rigshospitalet, University of Copenhagen, Copenhagen, Denmark ${ }^{3}$ Fetal Medicine Unit, Department of Obstetrics and Gynecology, Copenhagen University Hospital, Hvidovre, Denmark

${ }^{4}$ Section of Biostatistics, Faculty of Health and Medical Science, University of Copenhagen, Copenhagen, Denmark

${ }^{5}$ Department of Endocrinology, Rigshospitalet, University of Copenhagen, Copenhagen, Denmark

${ }^{6}$ Department of Plastic Surgery, Breast Surgery and Burns Treatment, Rigshospitalet, University of Copenhagen, Copenhagen, Denmark

Correspondence should be addressed to A M Andersson: Anna-Maria.Andersson@regionh.dk

\begin{abstract}
Background: Several chemical UV filters/absorbers ('UV filters' hereafter) have endocrine-disrupting properties in vitro and in vivo. Exposure to these chemicals, especially during prenatal development, is of concern.

Objectives: To examine maternal exposure to UV filters, associations with maternal thyroid hormone, with growth factor concentrations as well as to birth outcomes. Methods: Prospective study of 183 pregnant women with 2nd trimester serum and urine samples available. Maternal concentrations of the chemical UV filters benzophenone-1 (BP-1) and benzophenone-3 (BP-3) in urine and 4-hydroxy-benzophenone (4-HBP) in serum were measured by liquid chromatography-tandem mass spectrometry (LC-MS/MS). The relationships between 2nd trimester maternal concentrations of the three chemical UV filters and maternal serum concentrations of thyroid hormones and growth factors, as well as birth outcomes (weight, height, and head and abdominal circumferences) were examined.

Results: Positive associations between maternal serum concentrations of 4-HBP and triiodothyronine $\left(T_{3}\right)$, thyroxine $\left(T_{4}\right)$, insulin-like growth factor I (IGF-I) and its binding protein IGFBP3 were observed in mothers carrying male fetuses. Male infants of mothers in the middle 4-HBP exposure group had statistically significantly lower weight and shorter head and abdominal circumferences at birth compared to the low exposure group. Conclusions: Widespread exposure of pregnant women to chemical UV filters and the possible impact on maternal thyroid hormones and growth factors, and on fetal growth, calls for further studies on possible long-term consequences of the exposure to UV filters on fetal development and children's health.
\end{abstract}

Endocrine Connections (2018) 7, 334-346

\author{
Key Words \\ - UV filters \\ - 4-hydroxy-benzophenone \\ (4-HBP) \\ - birth outcome \\ - thyroid hormones \\ - growth factors
}

\section{Introduction}

Several recent studies have shown that human exposure to chemicals used as UV filters/absorbers is prevalent $(1,2,3$, $4,5)$. Exposure to UV filters occurs not only by intentional

$$
\begin{array}{lr}
\text { http://www.endocrineconnections.org } & \text { ○ } 2018 \text { The authors } \\
\text { https://doi.org/10.1530/EC-17-0375 } & \text { Published by Bioscientifica Ltd }
\end{array}
$$

use of sunscreens. Due to their ability to absorb UV light, UV filters are used as 'UV-absorbers' in a wide range of everyday products such as for protecting colors from

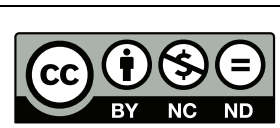

This work is licensed under a Creative Commons Attribution-NonCommercial-NoDerivatives 4.0 International License. 
bleaching, plastic from becoming friable in the sunlight or as photo-initiators in ink $(6,7,8,9,10,11,12)$. For practical reasons, we will refer to all of these chemicals as 'UV filters' throughout this paper, regardless of their use in industry. The widespread use of chemical UV filters results in human exposure throughout the year (2). The prevalent human exposure to UV filters is of concern as several of these chemicals have endocrine-disrupting properties demonstrated in in vitro animal and human studies (13, $14,15,16,17,18,19,20,21)$. We recently investigated the concentrations of seven different chemical UV filters in maternal blood and urine, and in amniotic fluid, and found that the UV filters benzophenone-1 (BP-1), benzophenone-3 (BP-3) and 4-hydroxybenzophenone (4-HBP) were present in the majority of pregnant women (3). Although concentrations were significantly lower in amniotic fluid samples, BP-1 and BP-3 as well as 4-HBP could also be found in the cord blood of several of the participants, indicating that these compounds might also cross the placenta and reach the fetus.

Successful intrauterine development of the human fetus is highly dependent on hormonal regulation, and disturbance of hormones during pregnancy might therefore have dramatic consequences for the development of the unborn child. In humans, urinary concentrations of BP-3 was associated with decrease in thyroid hormones in both background population and pregnant women (22, 23) and when measured in urine of pregnant women, BP-3 was associated with sex-dependent impact on birthweight (decreased in girls and increased in boys) (5) and decreased gestational length in boys (24). In the present study, we examined the associations of 2nd trimester maternal concentrations of three prevalently present UV filters (BP-1, BP-3 in maternal urine and 4-HBP in maternal serum) to maternal serum concentrations of thyroid hormones and growth factors and also to birth outcomes.

\section{Materials and methods}

\section{Study population and materials}

The study population consisted of participants in a study on the distribution of UV filters in urine, serum and amniotic fluid and consisted of 200 pregnant women undergoing amniocentesis at either Copenhagen University Hospital Hvidovre or Rigshospitalet. The study has previously been described in detail (3); in short, blood, urine and amniotic fluid samples were collected simultaneously from each woman during the second trimester of pregnancy when they arrived at the hospital for the amniocentesis procedure

$$
\text { http://www.endocrineconnections.org }
$$

during the period September 2012 to August 2014. In the current study, only results measured from blood and urine are included. The indication for amniocentesis varied but largely the women could be divided into three groups according to the severity of the amniocentesis indication and outcome: group 1: women referred for amniocentesis solely because of maternal request and/or high maternal age and found to carry fetuses with normal karyotype and normal results of ultrasound scan; group 2 women with increased risk for neural tube defects (NTDs), intestinal atresia, trisomy 18 or 21 or unspecific echogenic bowl on ultrasound scan, but who were found to carry a fetus without any malformations and with a normal karyotype and group 3: women carrying a fetus with either malformations found by ultrasound scan or with an abnormal karyotype, or both.

Information on maternal prepregnancy BMI, sex of the fetus, gestational age at sampling and at birth and birth outcome measured at delivery were all obtained from medical records.

Among the 200 pregnant women included in the study, 15 were excluded from analyses for the following reasons: medication for thyroid disease $(n=4)$, overtly pathological thyroid hormones at the time of sampling $(n=2)$, missing BMI information $(n=6)$ and missing infant sex information $(n=3)$ resulting in a total of 185 pregnant women. Due to missing serum samples from two of them, only 183 pregnant women were included in the analyses for thyroid hormones and growth factors collected at amniocentesis (study group 1, Fig. 1). Furthermore, 22 of the women had an abortion after the samples were collected and in 6 additional cases all birth outcome data were missing, resulting in 157 mother-child pairs for the birth outcome analyses based on urine samples and 155 mother-child pairs based on serum samples (study group 2, Fig. 1). One hundred fifty-five of the mother-child pairs were included in both the analyses of maternal hormone concentrations and birth outcomes in relation to UV filter concentrations.

All participants signed a declaration of informed consent prior to sample collection. The study was approved by The Ethics Committee of the Capital Region of Denmark (H-2-2012-76) and by The Danish Data Protection Agency (2012-58-0004).

\section{Hormone analyses}

Maternal serum samples were stored at $-20^{\circ} \mathrm{C}$ until analyzed in one batch in March 2016 for thyroid hormones and in March 2017 for growth factors, with 


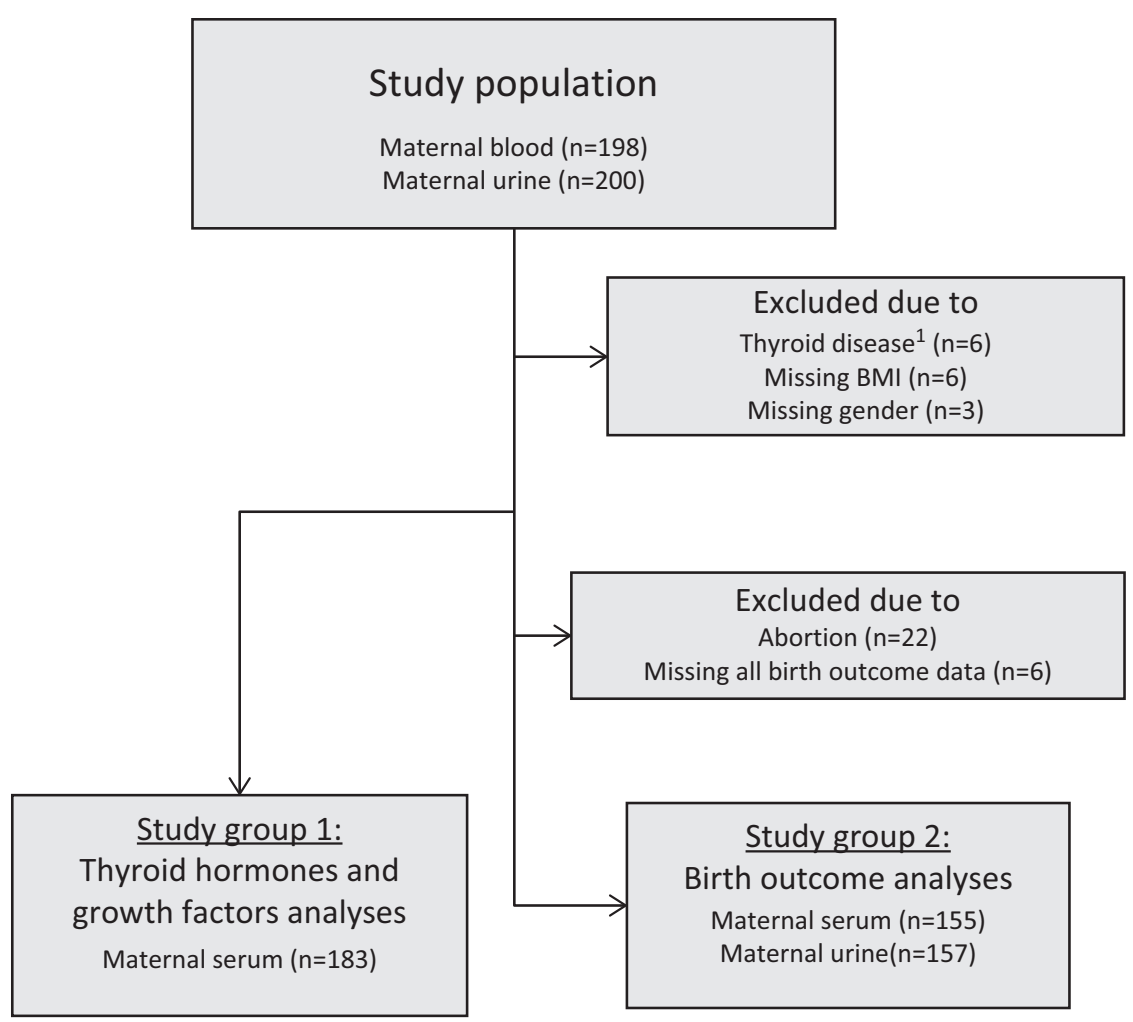

\section{Figure 1}

Study population and number of biological samples included in analyses on thyroid hormones and growth factors (study group 1) and in analyses on birth outcomes (study group 2). Includes medication for thyroid disease $(n=4)$ and overtly pathological thyroid hormones at the time of sampling $(n=2)$. the exception of two samples, which were analyzed for thyroid hormones in March 2017.

The thyroid hormones triiodothyronine $\left(\mathrm{T}_{3}\right)$, free triiodothyronine $\left(\mathrm{fT}_{3}\right)$, thyroxine $\left(\mathrm{T}_{4}\right)$ and free thyroxine $\left(\mathrm{fT}_{4}\right)$ were measured by competitive electrochemiluminescence immunoassays (ECLIA) and thyroid-stimulating hormone (TSH) by a sandwich electrochemiluminescence immunoassay (ECLIA) on a Cobas 8000, Modular e602 (Roche) at the Department of Clinical Biochemistry, Rigshospitalet, University of Copenhagen, Denmark. Interassay coefficients of variation were $<8 \%$ for all thyroid hormone assays. Limit of detection was $0.014 \mathrm{U} / \mathrm{L}, 0.3 \mathrm{nmol} / \mathrm{L}, 1.5 \mathrm{pmol} / \mathrm{L}$, $5.4 \mathrm{nmol} / \mathrm{L}$, and $3 \mathrm{pmol} / \mathrm{L}$ for $\mathrm{TSH}, \mathrm{T}_{3}, \mathrm{fT}_{3}, \mathrm{~T}_{4}$ and $\mathrm{fT}_{4}$, respectively.

Analyzed growth factors included insulin-like growth factor I (IGF-I) and its major binding protein: insulinlike growth factor-binding protein-3 (IGFBP3). IGF-I and IGFBP3 were both measured by a chemiluminescence immunoassay on the IDS-iSYS automated platform (Immuno Diagnostic Systems, IDS) at the Hormone Laboratory of the Department of Growth and Reproduction, Rigshospitalet, Copenhagen University, Denmark. Interassay coefficient of variation and limit of detection were respectively $<13 \%$ and below $80 \mu \mathrm{g} / \mathrm{L}$ for IGFBP3 and $<8 \%$ and $10 \mu \mathrm{g} / \mathrm{L}$ for IGF-I.

\section{Chemical analysis of UV filters}

Maternal urine and serum samples were analyzed for seven different UV filters by isotope dilution TurboFlow-liquid chromatography-tandem mass spectrometry (LC-MS/MS) (25), and the measured concentrations have previously been reported in detail (3). In the present study, only the three UV filters, which were present at concentrations above detection limits in more than $60 \%$ of samples are included: benzophenone-1 (BP-1) and benzophenone-3 (BP-3) in maternal urine and 4-hydroxy-benzophenone (4-HBP) in maternal serum. The octanol/water partition coefficients (log Kow) of these three benzophenones indicate that they are sufficiently hydrophilic to not bio accumulate and urine is usually the preferred matrix for this kind of substances. However, we have previously shown that in paired urine and serum samples from this study population, 4-HBP was more frequently present in detectable concentrations in serum ( $88 \%$ of the samples) than in urine (21\% of the samples) (3).

\section{Adjustment for urinary dilution}

In order to be able to adjust measured urinary concentrations of UV filters for the urinary dilution, the osmolality of the urine samples were measured by freezing point depression method with an automatic This work is licensed under a Creative Commons
Attribution-NonCommercial-NoDerivatives 4.0 International License. 
cryoscopic osmometer (Osmomat 030 from Gonotec, Berlin, Germany). Urinary osmolality was chosen as an adjustment method for urinary dilution as it was shown to be less affected by other exogenous factors in comparison to other known methods (26). Measured urinary UV filter concentrations were osmolality adjusted to account for urinary dilution using the following equation:

$$
C_{\text {corr }}=\frac{C_{i} \times \mathrm{Osm}_{\text {ref }}}{\text { Osm }_{\text {meas }}}
$$

where $C_{\text {corr }}$ is the corrected concentration, $C_{i}$ is the measured biomarker concentration, $\mathrm{Osm}_{\text {meas }}$ is the measured osmolality in the sample and $\mathrm{Osm}_{\text {ref }}$ is the reference osmolality value corresponding to the median osmolality of all the included urine samples $(=0.376 \mathrm{osmol} / \mathrm{kg})$.

\section{Statistical analyses}

Concentrations of UV filters below LOD were sat to the respective LOD divided by square root of two. The associations between measured concentrations of urinary BP-1, BP-3 and serum 4-HBP in pregnant women at 2nd trimester and their serum concentrations of thyroid hormones, the growth factors IGF-I and IGFBP3 as well as the birth outcomes of their infants were examined by General Linear Models (GLM). The exposure biomarkers were entered individually in the models as either a continuous or a categorical independent variable: concentrations of BP-3 and 4-HBP were grouped into the low, medium and high exposure categories based on the tertiles. For BP-1, the fraction of samples with undetectable concentrations exceeded 33\%, and for this compound, all undetectable samples were categorized to the low exposure group, while the rest of the samples were distributed equally into the medium and high exposure groups (for boundaries of the categories, Table 2). The distribution into low, medium and high exposure categories were made separately for models of associations with maternal thyroid hormones and growth factors and for models of association with birth outcomes because of a different number of samples included in the models of the different outcomes (Fig. 1).

Potential covariates in the study were maternal prepregnancy BMI (both as a continuous and a categorical $(<20,20-25,>25)$ variable), maternal smoking, parity, maternal age, maternal educational status, sex of the fetus and gestational age (either at time of sampling for models of associations with maternal hormones, or at birth for models of associations with birth outcomes) and season
(Summer = May-August, Winter $=$ September-April) of sampling. The influence of the potential covariates was checked by including them in the GLM one by one. Sex and gestational age of the infant and maternal BMI had all influence on statistical significance, defined as $P$ value below or above 0.05 of the final result of examined GLM. Gestational age at sampling and maternal prepregnancy BMI were entered as covariates in all analyses of the association with maternal hormones, while gestational age at birth and prepregnancy BMI were used as covariates in all analyses of the associations with birth outcomes. The impact of maternal prepregnancy BMI in the model was not linear and BMI was therefore included as a categorical variable $(<20,20-25$ and $>25)$. Furthermore, all analyses were stratified on the sex of the fetus because the concentrations of placental growth hormone (a major regulator of maternal IGF-I production during pregnancy) $(27,28)$ are known to be affected by fetal sex $(29,30)$, and birth outcomes in general are sex dimorphic (31).

In subsequent sensitivity analyses, we also included maternal smoking as a confounder in the full model of associations of the exposure biomarkers to birth outcomes because maternal smoking is well known to be associated with decreased birth weight (32). Likewise, in additional sensitivity analyses, we included season of sampling and season at birth as a confounder in the full model of associations of the exposure biomarkers to respectively maternal hormone concentrations and birth outcomes, showing that season did not have any significant impact on the results (data not shown).

Furthermore, as intrauterine growth retardation (IUGR) can be caused by several factors not related to endocrine factors, we repeated all analyses on birth outcome with exclusion of all IUGR pregnancies $(n=20$, IUGR defined according to the Danish national guideline as fetal weight below the 10th percentile for gestational age as determined through ultrasound) to see whether it changed the results of the final model.

Although UV filters concentrations were not normally distributed, transformation of the data was not necessary to achieve normal distribution and constant variance of the standardized residuals of GLM examined by visual inspection of the plots. All the statistical analyses described earlier were performed in IBM SPSS 22.

Due to the biological association between IGF-I and its binding protein IGFBP3, we calculated mediation proportion in order to examine whether observed associations of the exposure biomarkers to IGF-I were directly associated or possibly mediated through IGFBP3.

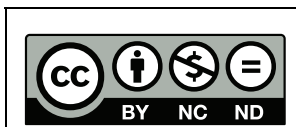

This work is licensed under a Creative Commons Attribution-NonCommercial-NoDerivatives 4.0 International License. 
Table 1 Characteristics of the included pregnant women.

\begin{tabular}{|c|c|c|c|c|c|}
\hline & All $(n=183)(100 \%)$ & AC group $1(n=41)(22 \%)$ & AC group $2(n=75)(41 \%)$ & AC group $3(n=67)(37 \%)$ & $P$ value ${ }^{a}$ \\
\hline Age (median (range)) & $34(21-44)$ & $37(27-42)$ & $34(21-42)$ & $33(21-44)$ & $0.003^{a, c}$ \\
\hline \multicolumn{6}{|l|}{ Education $(n(\%))$} \\
\hline High & $123(67.2)$ & $30(73.2)$ & $48(64.0)$ & $45(67.2)$ & \multirow[t]{3}{*}{$0.364^{\mathrm{e}}$} \\
\hline Middel & $31(16.9)$ & $8(19.5)$ & $15(20.0)$ & 8 (11.9) & \\
\hline Low & $27(14.8)$ & $3(7.3)$ & $12(16.0)$ & 12 (17.9) & \\
\hline \multicolumn{6}{|c|}{ Prepregnancy body mass index (BMI) $(n(\%))$} \\
\hline $\mathrm{BMI}: \leq 20$ & $39(21.3)$ & $7(17.1)$ & $22(29.3)$ & $10(14.9)$ & \multirow[t]{3}{*}{$0.005^{\mathrm{e}}$} \\
\hline BMI: >20-25 & $95(51.9)$ & $28(68.3)$ & $27(36.0)$ & $40(59.7)$ & \\
\hline BMI: $>25$ & $49(26.8)$ & $6(14.6)$ & $26(34.7)$ & $17(25.4)$ & \\
\hline \multicolumn{6}{|l|}{ Smoking $(n(\%))$} \\
\hline No smoking & $138(75.4)$ & $32(78.1)$ & $57(76.0)$ & $49(73.1)$ & \multirow[t]{4}{*}{$0.633^{e}$} \\
\hline Passive smoking & $32(17.5)$ & $6(14.6)$ & $13(17.3)$ & $13(19.4)$ & \\
\hline Nicotine & $5(2.7)$ & 0 & $2(2.7)$ & $3(4.5)$ & \\
\hline Smoking & $8(4.4)$ & $3(7.3)$ & $3(4.0)$ & $2(3.0)$ & \\
\hline \multicolumn{6}{|l|}{ Parity $(n(\%))$} \\
\hline Nuliparous & $69(37.7)$ & $13(31.7)$ & $28(37.3)$ & $28(41.8)$ & \multirow[t]{2}{*}{$0.574^{\mathrm{e}}$} \\
\hline Multiparous & $113(61.7)$ & $28(68.3)$ & $46(61.3)$ & $39(58.2)$ & \\
\hline \multicolumn{6}{|l|}{ Comorbidity $(n(\%))$} \\
\hline No comorbidity & $76(41.5)$ & $16(39.0)$ & $32(42.7)$ & $28(41.8)$ & \multirow[t]{3}{*}{$0.568^{\mathrm{e}}$} \\
\hline 1 comorbidity & $54(29.5)$ & $9(22.0)$ & $24(32.0)$ & $21(31.3)$ & \\
\hline$\geq 2$ comorbidities & $53(29.0)$ & $16(39.0)$ & $19(25.3)$ & $18(26.9)$ & \\
\hline $\begin{array}{l}\text { Pregnancy resulting in a } \\
\text { liveborn child }(n(\%))\end{array}$ & $161(88.0)$ & $40(97.6)$ & $75(100)$ & $46(68.7)$ & $<0.005^{\mathrm{a}, \mathrm{f}}$ \\
\hline $\begin{array}{l}\text { Gestational week at AC } \\
\text { (median (range)) }\end{array}$ & $18(12-36)$ & $16(15-36)$ & $16(12-25)$ & $20(15-34)$ & $<0.005^{\mathrm{a}, \mathrm{d}}$ \\
\hline \multicolumn{6}{|c|}{ Maternal serum hormone concentrations at AC (median (range)) } \\
\hline TSH (IU/L) & $1.8(0.1-6.5)$ & $1.8(0.7-6.5)$ & $1.7(0.2-4.0)$ & $2.0(0.1-4.1)$ & $0.077^{9}$ \\
\hline $\mathrm{T}_{3}(\mathrm{nmol} / \mathrm{L})$ & $2.4(1.5-3.9)$ & $2.3(1.5-3.5)$ & $2.4(1.7-3.9)$ & $2.4(1.7-3.6)$ & $0.131^{\mathrm{g}}$ \\
\hline $\mathrm{fT}_{3}(\mathrm{pmol} / \mathrm{L}$ & $4.6(3.5-6.1)$ & $4.6(3.5-5.6)$ & $4.7(3.8-5.8)$ & $4.7(3.8-6.1)$ & $0.703^{9}$ \\
\hline $\mathrm{T}_{4}(\mathrm{nmol} / \mathrm{L})$ & $143(96.7-214)$ & $139(97.3-175)$ & $146(96.7-212)$ & $141(101-214)$ & $0.103^{9}$ \\
\hline $\mathrm{fT}_{4}(\mathrm{pmol} / \mathrm{L})$ & $14.2(10.1-20.0)$ & $14.2(10.9-17.3)$ & $14.4(11.2-18.0)$ & $13.8(10.1-20.0)$ & $0.060^{\mathrm{g}}$ \\
\hline IGF-I ( $\mu \mathrm{g} / \mathrm{L})$ & $126(11.4-282)$ & $121(57.5-195)$ & $123(11.4-220)$ & $127(67.9-282)$ & $0.545^{9}$ \\
\hline IGFBP3 $(\mu \mathrm{g} / \mathrm{L})$ & $4846(3013-7961)$ & $4858(3013-7401)$ & $4794(3337-7961)$ & $4850(3369-7566)$ & $0.901^{9}$ \\
\hline \multicolumn{6}{|c|}{ Maternal UV filter concentrations at AC (median (range)) } \\
\hline uBP-1 (ng/mL) & $0.47($ LOD-665) & $0.60($ LOD-337) & $0.27($ LOD-665) & $0.57($ LOD-610) & $0.368^{\mathrm{g}}$ \\
\hline uBP-3 $(\mathrm{ng} / \mathrm{mL})^{b}$ & 2.57 (LOD-10,034) & 3.83 (LOD-1613) & 2.12 (LOD-10,034) & 2.60 (LOD-2986) & $0.539^{9}$ \\
\hline $\mathrm{s} 4-\mathrm{HBP}(\mathrm{ng} / \mathrm{mL})$ & $0.65($ LOD-1.96) & 0.54 (LOD-1.85) & 0.68 (LOD-1.87) & 0.70 (LOD-1.96) & $0.046^{\mathrm{a}, \mathrm{h}}$ \\
\hline
\end{tabular}

AC groups: Pregnancies stratified into three groups according to the severity of the indication for and outcome of the amniocentesis as described in the 'Materials and methods' section.

aStatistical significant differences between the AC groups, $P$-value $<0.05$; ${ }^{b}$ osmolality adjusted concentrations; 'Kruskal-Wallis test: Group 1 was significantly older than the other two groups; ${ }^{\mathrm{d} K r u s k a l-W a l l i s ~ t e s t: ~ G e s t a t i o n a l ~ a g e ~ a t ~ a m n i o c e n t e s i s ~ w a s ~ s i g n i f i c a n t l y ~ h i g h e r ~ i n ~ g r o u p ~ 3 ; ~}$

${ }^{\text {e }}$ Chi-square test; ${ }^{f}$ Chi-square test: Number of life born children was significantly lower in group 3; ${ }^{9}$ Kruskal-Wallis test; ${ }^{\text {h}}$ Kruskal-Wallis test: Serum concentrations of 4-HBP were significantly lower in group 1.

$\mathrm{AC}$, amniocentesis; $\mathrm{fT}_{3}$, free triiodidothyronine; $\mathrm{fT}_{4}$, free thyroxine; IGF-I, insulin-like growth factor I; IGFBP3, insulin-like growth factor binding protein 3; s4-HBP, serum 4-hydroxy benzophenone; $\mathrm{T}_{3}$, triiodothyronine; $\mathrm{T}_{4}$, thyroxine; $\mathrm{TSH}$, thyroid stimulating hormone; uBP-1, urinary benzophenone 1; uBP-3, urinary benzophenone 3 .

Calculations of mediation proportions were performed in the lava-package (version 1.5.1 (33)) in the statistical software 'R' (version 3.3.2 (34)).

\section{Results}

Basic characteristics of the women included in the study are presented in Table 1 for the full study group and stratified by three amniocentesis (AC) subgroups

$\begin{array}{lr}\text { http://www.endocrineconnections.org } & \text { ○ } 2018 \text { The authors } \\ \text { https://doi.org/10.1530/EC-17-0375 } & \text { Published by Bioscientifica Ltd }\end{array}$

based on the severity of the indication and outcome of the amniocentesis as indicated in the 'Materials and methods' section. Women in AC subgroup 1 were older and had statistically significantly lower 4-HBP serum concentrations than the two other subgroups. Supplementary statistical analyses showed that maternal 4-HBP levels were associated with age (data not shown) and the difference in 4-HBP concentrations between the AC group 1 and the two other groups could be explained

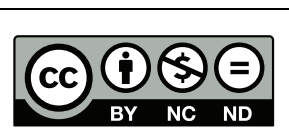
This work is licensed under a Creative Commons
Attribution-NonCommercial-NoDerivatives 4.0 International License. 
Table 2 Distribution of second trimester maternal urinary $(u)$ benzophenone-1 (BP-1) and benzophenone-3 (BP-3) concentrations ${ }^{\mathrm{a}}(\mathrm{ng} / \mathrm{mL})$ and serum (s) 4-hydroxy-benzophenone (4-HBP) concentrations $(\mathrm{ng} / \mathrm{mL})$.

\begin{tabular}{|c|c|c|c|c|c|c|c|c|}
\hline \multirow[b]{2}{*}{ UV filter } & \multirow[b]{2}{*}{$n>\operatorname{LOD}(\%)$} & \multirow[b]{2}{*}{ LOD $^{b}$} & \multirow[b]{2}{*}{ Min } & \multirow[b]{2}{*}{ Median } & \multicolumn{3}{|c|}{ Exposure groups } & \multirow[b]{2}{*}{ Max } \\
\hline & & & & & Low $(n)$ & Middle $(n)$ & High & \\
\hline UBP-1 & $119(65)$ & 0.25 & $<$ LOD & 0.47 & $<\operatorname{LOD}(68)^{c}$ & $0.25-1.61(58)$ & $>1.61(57)$ & 665 \\
\hline UBP-3 & $168(92)$ & 0.28 & $<L O D$ & 2.57 & $<1.23(61)$ & $1.23-6.66(61)$ & $>6.66(61)$ & 10,034 \\
\hline s4-HBP & $161(88)$ & 0.18 & $<L O D$ & 0.65 & $<0.48(61)$ & $0.48-0.83(61)$ & $>0.83(61)$ & 1.96 \\
\hline
\end{tabular}

Stratification into exposure tertiles is based on study population $1(n=183)$.

a Osmolality adjusted concentrations; blimit of detection $(\mathrm{ng} / \mathrm{mL})$ for raw measurements before osmolality adjustment; 'the number of samples in the low exposure group to BP-1 exceeds the number of samples below LOD because four samples in the low exposure group to BP-1 were >LOD before osmolality adjustment but gave a value $<0.25(\mathrm{ng} / \mathrm{mL})$ after osmolality adjustment.

by the difference in age. As the three subgroups did not differ significantly from each other on any of the other parameters studied, all subsequent analyses were done on the full study group.

The distribution of maternal urinary BP-1 and BP-3 concentrations and maternal serum 4-HBP concentrations in the three exposure groups used when modeling exposure as a categorical variable are shown in Table 2 . Median and range of the birth outcomes of the infants, obtained from medical records, are shown in Table 3 stratified by sex of the child.

\section{Associations between maternal UV filter concentrations and maternal thyroid hormones and growth factors}

For maternal urinary BP-1 and BP-3 concentrations, no statistically significant associations ( $P$ values: $>0.05$ ) to maternal thyroid hormones, IGF-I or IGFBP3 were observed (data not shown).

For women carrying a male fetus, we observed significant positive associations between maternal serum 4-HBP concentrations and maternal $\mathrm{T}_{3}, \mathrm{~T}_{4}$, IGF-I and IGFBP3 concentrations when adjusted for gestational age at sampling. These associations remained significant for IGF-I and IGFBP3 when additionally adjusted for prepregnancy BMI (Supplementary Table 1.1, see section on supplementary data given at the end of this article). The effect estimates indicated that an increase of $1 \mathrm{ng} / \mathrm{mL}$ in maternal 4-HBP serum concentrations was associated with an average increase in maternal serum concentrations of $\mathrm{T}_{3}$ of $0.27 \mathrm{nmol} / \mathrm{L}$ (95\% CI: 0.05-0.49, $P=0.02)$ and $\mathrm{T}_{4}$ of $11.9 \mathrm{nmol} / \mathrm{L}(95 \% \mathrm{CI}: 0.66-23.0$, $P=0.04)$ when adjusted for gestational age at sampling, and an increase in IGF-I of $19 \mu \mathrm{g} / \mathrm{L}$ (95\% CI: $1.4-37$, $P=0.04)$ and IGFBP3 of $516 \mu \mathrm{g} / \mathrm{L}$ (95\% CI: 72.8-959, $P=0.02)$ when adjusted for both gestational age and maternal prepregnancy BMI.

$$
\begin{aligned}
& \text { http://www.endocrineconnections.org } \\
& \text { https://doi.org/10.1530/EC-17-0375 }
\end{aligned}
$$

For women carrying a female fetus, no associations between maternal serum 4-HBP and maternal $\mathrm{T}_{3}$ or $\mathrm{T}_{4}$ were observed (Supplementary Table 1.2) but instead a significant negative association with maternal $\mathrm{fT}_{4}$ concentrations was observed. The effect estimates indicate that an increase of $1 \mathrm{ng} / \mathrm{mL}$ in 4 -HBP serum concentrations was associated with an average decrease of maternal $\mathrm{fT}_{4}$ serum concentrations of $1 \mathrm{pmol} / \mathrm{L}$ (95\% CI: -0.14 to $(-1.88), P=0.02)$. The associations between maternal serum 4-HBP and maternal growth factors were less pronounced for women carrying a female fetus, although a positive trend with serum IGFBP3 concentrations was still evident, with women in the highest exposure group having significantly higher IGFBP3 serum concentrations than women in the lowest exposure group $(P=0.04)$. Effect estimates for the association between maternal serum 4-HBP and maternal serum IGFBP3 were of the same order as observed for women carrying a male fetus.

Serum IGF-I and IGFBP3 concentrations are known to be highly correlated (27) and in order to test whether the association between maternal serum 4-HBP and maternal

Table 3 Median and range for birth outcome variables in

\begin{tabular}{|c|c|c|c|}
\hline & Median & Min & Max \\
\hline \multicolumn{4}{|l|}{ Female infants $(n=72)$} \\
\hline Gestational age (weeks) & 39 & 33 & 42 \\
\hline Weight (g) & 3246 & 1351 & 4385 \\
\hline Length $(\mathrm{cm})^{a}$ & 50 & 42 & 57 \\
\hline Head cir. $(\mathrm{cm})^{\mathrm{a}}$ & 34 & 29 & 38 \\
\hline Abdominal cir. $(\mathrm{cm})^{\mathrm{b}}$ & 32 & 22 & 38 \\
\hline \multicolumn{4}{|l|}{ Male infants $(n=85)$} \\
\hline Gestational age (weeks) & 40 & 32 & 42 \\
\hline Weight $(g)^{c}$ & 3494 & 1560 & 4916 \\
\hline Length $(\mathrm{cm})$ & 51 & 39 & 56 \\
\hline Head cir. (cm) & 35 & 28 & 38 \\
\hline Abdominal cir. $(\mathrm{cm})^{\mathrm{b}}$ & 33 & 26 & 38 \\
\hline
\end{tabular}
the newborn girls and boys.

aBirth length and birth head circumference in female infants were available only in 71 cases; birth abdominal circumferences were available only in 83 cases for male infants and in 68 cases for female infants; "birth weight for male infants was available only in 84 cases.

This work is licensed under a Creative Commons Attribution-NonCommercial-NoDerivatives 4.0 International License. 
IGF-I was modified by IGFBP3 concentrations, we calculated the mediation coefficients for the association of 4-HBP concentrations in maternal serum on IGFBP3 and IGF-I split by sex of the fetus (Table 4). It was estimated that in the boys, $35 \%$ of the association of serum 4-HBP to maternal IGF-I could be mediated via an association with IGFBP3 serum concentrations $(P=0.05)$.

\section{Associations between maternal UV filter concentrations in the second trimester and birth outcomes}

For male infants of the mothers in the medium 4-HBP exposure group, we observed significantly lower birth weight and smaller head and abdominal circumferences ( $P=0.04 ; P=0.04 ; P=0.008$ respectively). These associations remained significant when adjusted for gestational age at birth and prepregnancy BMI (Fig. 2 and Supplementary Table 2). Adjustment for smoking did not change the results (data not shown). The effect estimates indicate that boys of mothers from the medium 4-HBP exposure group at birth were on average $240 \mathrm{~g}$ lighter, $8 \mathrm{~mm}$ smaller in head circumference, and $1.6 \mathrm{~cm}$ smaller in abdominal circumference compared to boys of mothers in the low exposure group when adjusted for prepregnancy BMI and gestational age at birth. When IUGR pregnancies were excluded from the models, negative associations with head and abdominal circumferences in male infants of mothers in the medium exposure group were still significant $(P=0.05$ and $P=0.01$, respectively (data not shown)). When 4-HBP concentrations were included in the model as continuous variable, we did not observe any significant association between maternal serum 4-HBP

Table 4 Mediation coefficient for the estimated effect of $1 \mathrm{ng} / \mathrm{mL}$ increase in 4-hydroxybenzophenone (4-HBP) concentrations in maternal serum on insulin-like growth factor I (IGF-I) ( $\mu \mathrm{g} / \mathrm{L})$ directly or indirectly mediated by insulin-like growth factor binding protein 3 (IGFBP3).

\begin{tabular}{|c|c|c|c|c|c|}
\hline Effect & $\begin{array}{l}\text { Mediation } \\
\text { coefficient }\end{array}$ & $95 \%$ & & $\begin{array}{c}\% \text { of } \\
\text { the } \\
\text { effect }\end{array}$ & P-Value \\
\hline \multicolumn{6}{|l|}{ Male } \\
\hline Total & 19.3 & 2.65 & 36.0 & 100 & 0.02 \\
\hline Direct & 12.5 & -3.65 & 28.6 & 65 & 0.13 \\
\hline Indirect & 6.84 & 0.04 & 13.64 & 35 & 0.05 \\
\hline \multicolumn{6}{|l|}{ Female } \\
\hline Total & 10.8 & -10.5 & 32.1 & 100 & 0.32 \\
\hline Direct & 4.27 & -16.5 & 25.0 & 40 & 0.69 \\
\hline Indirect & 6.52 & -1.31 & 14.4 & 60 & 0.10 \\
\hline
\end{tabular}

Cl, confidence interval. concentrations in the second trimester and any of the recorded birth outcomes in male infants (Supplementary Table 2).

For female infants, there was no significant association between maternal serum 4-HBP concentrations in the second trimester and any of the recorded birth outcomes (Supplementary Table 2), when adjusting for gestational age at birth. However, in the model where IUGR pregnancies $(n=20)$ were excluded, we observed a significantly positive association between maternal serum concentrations of 4-HBP and birth length and head circumference in female infants both when the 4-HBP serum concentration were used as a continuous $(P=0.03$ and $P=0.02$ respectively) and a categorical (trend $P=0.05$ and trend $P=0.04$ respectively) exposure marker (data not shown).

For mothers carrying a male fetus, we observed significantly negative associations of abdominal circumference at birth with maternal urinary concentrations of BP-1 $(P$ value $=0.01)$ and BP-3 $(P$ value $<0.007$ ) (data not shown). However, this association was driven by a single mother, who had very high BP-1 (665 ng/mL) and BP-3 (5893 $\mathrm{ng} / \mathrm{mL})$ urinary concentrations compared to the other women and whose son was one of the smallest in the study in spite of being born at term. When this mother-child pair was excluded from the models, the associations between BP-1 and BP-3 and abdominal circumference were no longer statistically significant. Also one of the mothers carrying a female fetus had high urinary concentrations of BP-1 and BP-3 (612 ng/mL and 10,034 ng/mL, respectively). No significant associations between maternal urinary concentrations of BP-1 and BP-3 and birth outcomes in female fetuses were observed, regardless if this high exposed mother-female infant pair was included in the model or not.

\section{Discussion}

In our prospective study of 183 pregnant women, we examined the relationship between 2nd trimester exposure to UV filters of the benzophenone type and maternal thyroid hormones, growth factors and birth variable outcomes. We found statistically significant positive association between 4-HBP concentrations in maternal serum and $\mathrm{T}_{4}$, IGF-I and IGFBP3 in mothers carrying male fetuses. Furthermore, we observed consistent negative associations in male offspring between maternal serum concentrations of 4-HBP and all birth endpoints, although only statistically significant for

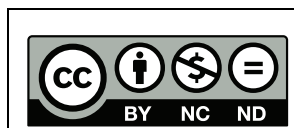

This work is licensed under a Creative Commons Attribution-NonCommercial-NoDerivatives 4.0 International License. 

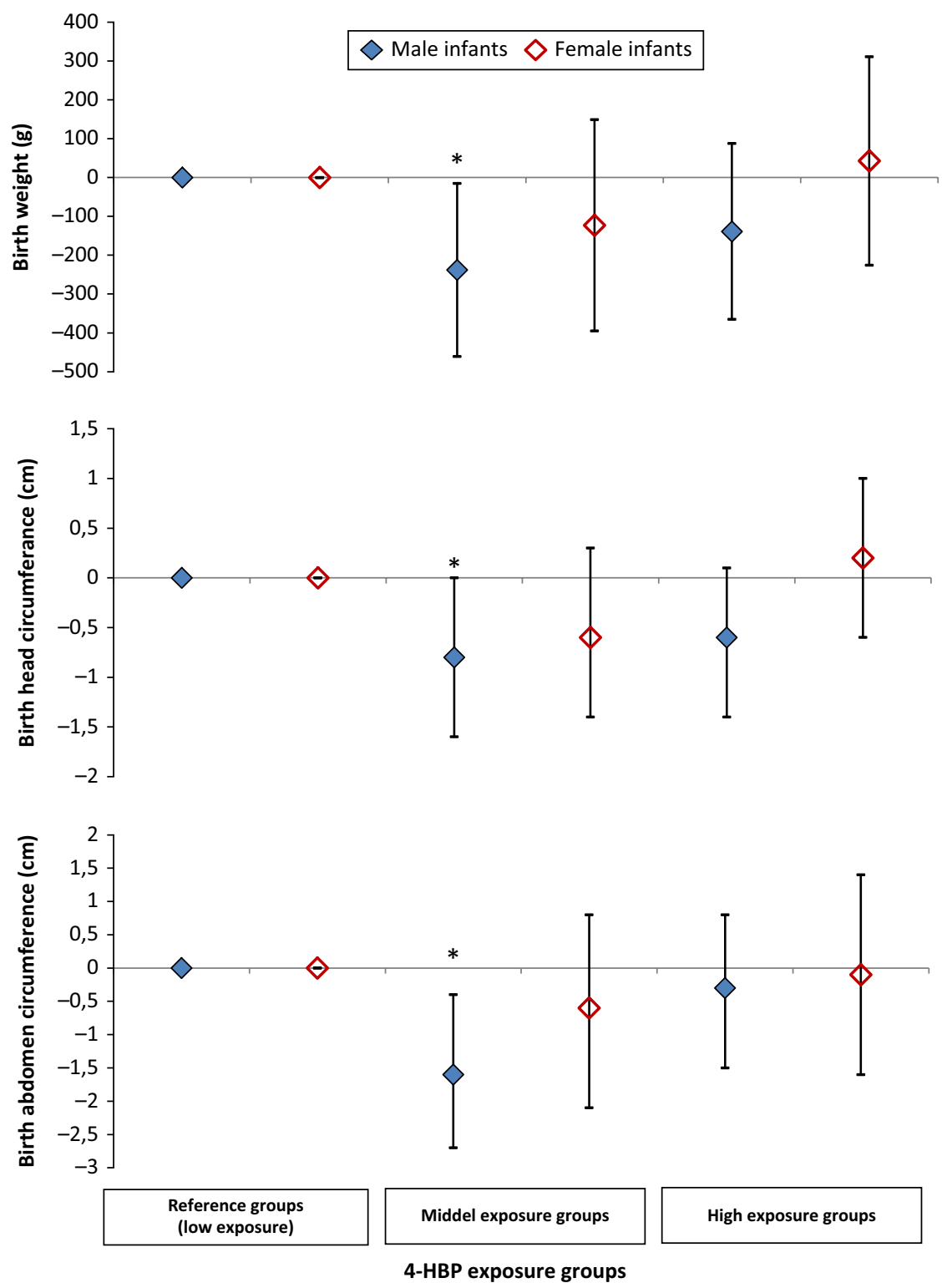

Figure 2

Associations between maternal exposure to 4-HBP (low: $<0.48(\mathrm{ng} / \mathrm{mL})(n=51)$ middle: $0.48-0.788(\mathrm{ng} / \mathrm{mL})(n=52)$ and high: $>0.788(\mathrm{ng} /$ $\mathrm{mL})(n=52))$ and birth outcomes in male $(n=85)$ and female infants $(n=72)$. Stratification into exposure tertiles is based on study group 2 $(n=155) . * P<0.05$

birth weight, head and abdominal circumferences, and only for sons of mothers in the middle exposure range. Thus, the associations between 4-HBP and birth outcomes appeared to be U-shaped rather than linear. A nonmonotonic dose-response relationship is a phenomenon that has been demonstrated in experimental studies for endocrine-disrupting effects of several chemicals $(35,36)$, and we speculate that 4-HBP might act in the same way in humans.

With regard to the UV filters BP-1 and BP-3, we did not observe any associations between maternal urinary concentrations and either maternal thyroid hormones, growth factors or birth outcomes. To our knowledge, BP-3 is the only chemical UV filter for which maternal exposure has previously been examined in humans in relation to

$$
\begin{array}{lr}
\text { http://www.endocrineconnections.org } & \text { ○ } 2018 \text { The authors } \\
\text { https://doi.org/10.1530/EC-17-0375 } & \text { Published by Bioscientifica Ltd }
\end{array}
$$

maternal thyroid hormones and birth outcomes. A recent study reported negative association between maternal urinary BP-3 and serum $\mathrm{fT}_{3}$ concentrations (22). In that study, the concentrations of BP-3 found in maternal urine were about 3- 4-fold higher than those in our study population. Furthermore, they did not analyze their data stratified by sex of the infant. These differences could possibly explain the difference in findings between the two studies.

Results of previous studies regarding associations between maternal urinary BP-3 concentrations and birth outcome are equivocal as associations between maternal urinary BP-3 concentrations were observed to be either positively associated with birth weight in boys and negatively associated with birth weight in girls (5) or not 
associated to birth weight at all $(4,24)$. Maternal urinary BP-3 concentrations in the American study (5), which observed associations with birth weight, were on average 3-fold higher than those observed in our Danish study population and in a French study population (4) and 100-fold higher than those observed in a Chinese study population (24); all of which did not observe a significant associations for BP-3 to birth weight. It is possible that associations between maternal BP-3 concentrations and birth weight are only observed at BP-3 exposure level higher than those measured in our study; a study with a larger range of exposure levels would be required to demonstrate whether this is the case.

Maternal exposure to endocrine-disrupting chemicals can affect the fetus by acting directly on the fetus if the fetus is co-exposed through placental transfer of the chemical. However, endocrine-disrupting effects can also affect the fetus indirectly via changes in maternal hormone concentrations, including thyroid hormones (37) and growth factors $(38,39,40,41)$. We observed associations between maternal serum concentrations of 4-HBP and maternal thyroid status, and interestingly, the observed associations differed depending on the sex of the fetus. For mothers carrying a female fetus, the effect estimates indicate that, in relation to median $\mathrm{fT}_{4}$ concentrations, the highest exposed mothers might have on average $12 \%$ lower $\mathrm{fT}_{4}$ concentrations compared to the lowest exposed mothers. For mothers carrying a male fetus, the highest exposed mothers might have on average 20\% and $22 \%$ higher serum $\mathrm{T}_{3}$ and $\mathrm{T}_{4}$ concentrations, respectively, than the lowest exposed mothers. During pregnancy, the fetus is highly dependent on maternal thyroid hormone function, especially during the first 20 weeks of gestation. Thyroid receptors, thyroid receptor gene expression and prereceptor control mechanisms are detected in fetal tissues as early as at gestational week 7 (42, 43), demonstrating the importance of thyroid hormones for fetal development already in early pregnancy, long before the fetus's own thyroid hormone production initiates around gestational week 11 and is fully established around mid-gestation (44). Experimental studies indicate that the active hormone $\mathrm{T}_{3}$ is not transferred from the mother to the fetus; the fetal source comes from metabolism of maternal $\mathrm{T}_{4}$ reaching fetal tissue; thus, only $\mathrm{fT}_{4}$ passes the placental barrier from maternal circulation to meet the fetal requirements (45). Even at term, 30\% of the fetal thyroid hormones are of maternal origin (44). Low maternal concentrations of $\mathrm{fT}_{4}$ during early pregnancy, as we observed in the high 4-HBP exposed women carrying a female fetus, have been shown to affect both verbal and nonverbal cognitive function of infants later in life (46). Hyperthyroidism during pregnancy has, on the other hand, been shown to be associated with increased risk of low birth weight and being small for gestational age $(47,48)$, which is in agreement with our observation of 4-HBP exposure in women carrying a male fetus being associated with both increased maternal thyroid hormone concentrations and decreased fetal growth. Thus, it is possible that the association with birth size of male offspring in mothers of the middle exposure group to 4-HBP could be mediated by an increase in their thyroid hormones. However, we have previously shown that 4-HBP also might enter the fetal circulation and hence might also act directly on the fetus (3).

We also observed positive associations between maternal serum concentrations of 4-HBP and of the growth factor IGF-I and its major binding protein IGFBP3. During pregnancy, maternal serum concentrations of IGF-I and IGFBP3 increase to reach a maximum at approximately 37 weeks of gestation (27). This increase is positively associated with an increase in placentalderived growth hormone (pGH), which is detectable in maternal serum from week 8 (49) and gradually takes over the function of maternal pituitary growth hormone, which concurrently decrease during pregnancy (38). In the second trimester, pGH therefore plays an important role in stimulating maternal IGF-I production $(38,50)$ (and indirectly also IGFBP3 production (27)). Maternal IGF-I on the other hand stimulates placental nutrition transport to the fetus $(51,52,53,54)$. Maternal IGF-I has been shown to be associated with placental weight and is believed to be indirectly responsible for fetal growth (27). It therefore seems contradictive that maternal exposure to 4-HBP is associated with both increased maternal IGF-1 concentrations and decreased fetal growth as we observed for the boys.

4-HBP is known to be one of the metabolites of benzophenone (BP), and the measured maternal serum concentrations of 4-HBP may therefore, at least partly, originate from exposure to BP and maternal metabolism of BP into 4-HBP (55). However, 4-HBP is also in itself used in industry as a UV absorber and in the manufacture of other substances (6) but not in sunscreens or other personal care products (9). BP is also not allowed to be used in sunscreens as a UV filter, but is still allowed for use in personal care products as flavoring and perfume fixation. In addition, BP is used in washing agents, painting, fillers, pharmaceuticals, lacquers, furniture, electrical equipment and flavoring in candies, and also as a photo-initiator, surfacing and a wetting agent in inks, which often lead to its presence in 
recycled paper (10). Experimental studies elucidating effects of 4-HBP exposure are limited but 4-HBP exposure has been reported to exhibit an estrogenic activity both in vitro and in vivo, while the parent compound BP only shows a weak or no estrogenic activity $(16,21,56)$. In humans, maternal urinary 4-HBP concentrations have been associated with a skewed sex ratio with an excess of male birth (13). BP has been shown in vitro to decrease thyroid peroxidase (TPO) activity that plays an important role in thyroid hormone synthesis (20). We do not know if BP is metabolized to 4 -HBP in the used in vitro model (a follicular thyroid carcinama cell line) and the observed effect therefore potentially could be mediated (partly) by 4-HBP. With a decrease in TPO activity reduced $\mathrm{T}_{3}$ and $\mathrm{T}_{4}$ synthesis would be expected, which is the opposit of our findings where we observe higher $\mathrm{T}_{3}$ and $\mathrm{T}_{4}$ concentrations with higher 4-HBP concentrations in mothers carrying male infants. However, in contrast to an in vitro model, all the compensatory feed back mechanisms are active in our pregnant women and an effect observed in an in vitro system is therefore difficult to translate into potential effects in vivo.

\section{Limitations and strengths of the study}

A limitation of our study is that maternal exposure was estimated based on single spot urine and serum samples. The benzophenone type UV filters are non-persistent chemicals that are expected to be excreted within a few days (depending on the chemical) and thus a concentration measured at a given time reflects only recent exposure. However, intra-individual urinary concentrations of BP-3 have previously been shown to have a relatively high interclass correlation coefficient (ICC) ranging from 0.46 to $0.81(57,58,59)$ and was demonstrated to be well correlated with other spot samples taken during a longer period within the same individual $(59,60,61)$. Therefore, at least for BP-3 but most likely also for BP-1 and 4-HBP, the concentrations measured in a single spot sample is assumed to represent quite well a person's general exposure level. Furthermore, based on our previous study examining several UV filters in different matrices (3), we were able to focus on the most appropriate matrices for BP-1, BP-3 and 4-HBP exposure in this study.

The gold standard for measurement of free thyroid hormones ( $\mathrm{fT}_{3}$ and $\mathrm{fT}_{4}$ ) is a method involving a separation step of bound from free thyroid hormone, classically a dialysis method (62) or recently the LC/MS method; but none of these methods are widely available. In our study, free thyroid hormones were measured by an immunoassay. Immunoassays can both overestimate and underestimate free thyroid hormone concentrations depending on the platform used for the assay (62). However, there is no reason to suspect that a potential overestimation of free $\mathrm{T}_{3}$ and free $\mathrm{T}_{4}$ serum concentrations should be biased in relation to the exposure to UV filters and thereby might not have affected the results.

Sample size is always a challenge in studies like this and is limited both by recruitment and cost of analyses. Our study population was a selected group of women undergoing amniocentesis. However, with regard to their exposure to UV filters, we do not think that they are biased compared to the general population for the following reasons: (1) when adjusting for the age of the mother, no significant difference in exposure levels were observed between the women carrying a fetus with malformations or abnormal karyotype and the women carrying a healthy fetus with maternal age or wish as only indication for the amniocentesis procedure and (2) the concentrations of maternal urinary BP-1 and BP-3 measured in our study population was comparable to the concentrations recently measured in pregnant women from the general population (1).

We analyzed the associations of exposure to three different UV filters against seven different hormones and four different birth outcomes, resulting in a large number of tests which increased the risk of a significant result being a chance finding. We thus cannot exclude that some of our significant associations were chance findings. However, the reported findings, especially those observed in male infants, all point in the same direction and are in mutual biological agreement, making them plausible true findings.

\section{Conclusion}

In conclusion, in this prospective study of 183 motherchild pairs, we found associations between maternal serum concentrations of the UV filter 4-HBP (used a UV absorber in industrial products) and decrease in birth weight, birth abdominal- and head circumference in male infants. In addition, we found an association with changes in thyroid hormone concentrations and growth factors, predominantly in mothers carrying male fetuses. Those findings are of concern and call for further studies on possible long-term consequences of exposure to UV filters for fetal development and children's health.

\section{Supplementary data}

This is linked to the online version of the paper at https://doi.org/10.1530/ EC-17-0375. 


\section{Declaration of interest}

The authors declare that there is no conflict of interest that could be perceived as prejudicing the impartiality of the research reported.

\section{Funding}

Financial support was obtained from the Danish Environmental Protection Agency (Miljøstyrelsen: MST-621-00148) and from Kirsten and Freddy Johansons Foundation (F-22079-08). The research salary of $U$ FeldtRasmussen was sponsored by an unrestricted research grant from the Novo Nordisk Research Fund.

\section{Acknowledgements}

The authors are very grateful to the pregnant women participating in the study and staff involved in the recruitment process, collection and analyses of samples and logistical collaboration. Individual thanks to Anette Jaeger, midwife and Carsten Henriques, MD from Center of Fetal Medicine and Pregnancy at Rigshospitalet and Marianne Danielsen, secretary from The Department of Clinical Genetics, Rigshospital. They appreciate assistance to grammatical proofreading of the article by $\mathrm{Dr}$ Kenneth M Grigor.

\section{References}

1 Frederiksen H. Human urinary excretion of non-persistent environmental chemicals: an overview of Danish data collected between 2006 and 2012. Reproduction 2014147 555-565. (https:// doi.org/10.1530/REP-13-0522)

2 Krause M, Andersson AM, Skakkebaek NE \& Frederiksen H. Exposure to UV filters during summer and winter in Danish kindergarten children. Environment International 201799 177-184. (https://doi. org/10.1016/j.envint.2016.11.011)

3 Krause M, Frederiksen H, Sundberg K, Jorgensen FS, Jensen LN, Norgaard P, Jørgensen C, Ertberg P, Juul A, Drzewiecki KT, et al. Presence of benzophenones commonly used as UV filters and absorbers in paired maternal and fetal samples. Environment International 2017110 51-60. (https://doi.org/10.1016/j. envint.2017.10.005)

4 Philippat C, Botton J, Calafat AM, Ye X, Charles MA \& Slama R. Prenatal exposure to phenols and growth in boys. Epidemiology 2014 25 625-635. (https://doi.org/10.1097/EDE.0000000000000132)

5 Wolff MS, Engel SM, Berkowitz GS, Ye X, Silva MJ, Zhu C, Wetmur J \& Calafat AM. Prenatal phenol and phthalate exposures and birth outcomes. Environmental Health Perspectives 2008116 1092-1097. (https://doi.org/10.1289/ehp.11007)

6 ECHA. Database of the European Chemicals Agency. Helsinki, Finland: ECHA, 2017. (available at: https://echa.europa.eu/da/searchfor-chemicals)

7 European Commission. Regulation (EC) No 1223/2009 of the European Parliament and of the Council of 30 November 2009 on cosmetic products. Official Journal of the European Union, 2009. (available at: http://eur-lex.europa.eu/legal-content/EN/TXT/PDF/?ur $\mathrm{i}=$ CELEX:32009R1223\&qid=1506951667669\&from=EN)

8 European Commission. Annex VI, last update: 14/09/2017 list of UV filters allowed in cosmetic products. CosIng Database. Brussels, Belgium: European Commission, 2017. (available at: http://ec.europa.eu/growth/tools-databases/cosing/pdf/COSING_ Annex\%20VI_v2.pdf)

9 European Commission. Annex VI, list of UV filters allowed in cosmetic products. Brussels, Belgium: European Commission, 2017. (available at: https://data.europa.eu/euodp/da/data/dataset/cosmeticingredient-database-list-of-uv-filters-allowed-in-cosmetic-products)
10 International Agency for Research on Cancer. Some chemicals present in industrial and consumer products, food and drinkingwater. In IARC Monographs on the Evaluation of Carcinogenic Risks to Humans. Lyon, France: International Agency for Research on Cancer, 2013.

11 International Chemical Secretariat. SIN LIST 2.0. Göteborg, Sweden: chemsec 2017. (available at: http://sinlist.chemsec.org/)

12 Mikkelsen SH, Lassen C, Warming M, Hansen E, Brinch A, Brooke D, Crookes M, Nielsen E \& Bredsdorff L. Survey and health assessment of UV filters. In Survey of Chemical Substances in Consumer Products. Copenhagen, Denmark: The Danish Environmental Protection Agency, 2015.

13 Bae J, Kim S, Kannan K \& Buck Louis GM. Couples' urinary concentrations of benzophenone-type ultraviolet filters and the secondary sex ratio. Science of the Total Environment 2016543 28-36. (https://doi.org/10.1016/j.scitotenv.2015.11.019)

14 Kinnberg KL, Petersen GI, Albrektsen M, Minghlani M, Awad SM, Holbech BF, Green JW, Bjerregaard P \& Holbech H. Endocrinedisrupting effect of the ultraviolet filter benzophenone-3 in zebrafish, Danio rerio. Environmental Toxicology and Chemistry 201534 2833-2840. (https://doi.org/10.1002/etc.3129)

15 Kunisue T, Chen Z, Buck Louis GM, Sundaram R, Hediger ML, Sun L \& Kannan K. Urinary concentrations of benzophenone-type UV filters in U.S. women and their association with endometriosis. Environmental Science and Technology 201246 4624-4632. (https:// doi.org/10.1021/es204415a)

16 Nakagawa Y \& Tayama K. Estrogenic potency of benzophenone and its metabolites in juvenile female rats. Archives of Toxicology 200175 74-79. (https://doi.org/10.1007/s002040100225)

17 Nashev LG, Schuster D, Laggner C, Sodha S, Langer T, Wolber G \& Odermatt A. The UV-filter benzophenone-1 inhibits 17 betahydroxysteroid dehydrogenase type 3: virtual screening as a strategy to identify potential endocrine disrupting chemicals. Biochemical Pharmacology 201079 1189-1199. (https://doi.org/10.1016/j. bcp.2009.12.005)

18 Pollack AZ, Buck Louis GM, Chen Z, Sun L, Trabert B, Guo Y \& Kannan K. Bisphenol A, benzophenone-type ultraviolet filters, and phthalates in relation to uterine leiomyoma. Environmental Research 2015137 101-107. (https://doi.org/10.1016/j.envres.2014.06.028)

19 Schmutzler C, Gotthardt I, Hofmann PJ, Radovic B, Kovacs G, Stemmler L, Nobis I, Bacinski A, Mentrup B, Ambrugger P, et al. Endocrine disruptors and the thyroid gland - a combined in vitro and in vivo analysis of potential new biomarkers. Environmental Health Perspectives 2007115 (Supplement 1) 77-83. (https://doi. org/10.1289/ehp.9369)

20 Song M, Kim YJ, Song MK, Choi HS, Park YK \& Ryu JC. Identification of classifiers for increase or decrease of thyroid peroxidase activity in the FTC-238/hTPO recombinant cell line. Environmental Science and Technology 201145 7906-7914. (https://doi.org/10.1021/es200475k)

21 Suzuki T, Kitamura S, Khota R, Sugihara K, Fujimoto N \& Ohta S. Estrogenic and antiandrogenic activities of 17 benzophenone derivatives used as UV stabilizers and sunscreens. Toxicology and Applied Pharmacology 2005203 9-17. (https://doi.org/10.1016/j. taap.2004.07.005)

22 Aker AM, Watkins DJ, Johns LE, Ferguson KK, Soldin OP, Anzalota Del Toro LV, Alshawabkeh AN, Cordero JF \& Meeker JD. Phenols and parabens in relation to reproductive and thyroid hormones in pregnant women. Environmental Research 2016151 30-37. (https:// doi.org/10.1016/j.envres.2016.07.00)

23 Kim S, Kim S, Won S \& Choi K. Considering common sources of exposure in association studies - urinary benzophenone-3 and DEHP metabolites are associated with altered thyroid hormone balance in the NHANES 2007-2008. Environment International 2017107 25-32. (https://doi.org/10.1016/j.envint.2017.06.013)

24 Tang R, Chen MJ, Ding GD, Chen XJ, Han XM, Zhou K, Chen LM, Xia YK, Tian Y \& Wang XR. Associations of prenatal exposure to http://www.endocrineconnections.org https://doi.org/10.1530/EC-17-0375
(๔) 2018 The authors Published by Bioscientifica Ltd
This work is licensed under a Creative Commons Attribution-NonCommercial-NoDerivatives 4.0 International License. 
phenols with birth outcomes. Environmental Pollution 2013178 115-120. (https://doi.org/10.1016/j.envpol.2013.03.023)

25 Frederiksen H, Nielsen O, Skakkebaek NE, Juul A \& Andersson AM. UV filters analyzed by isotope diluted TurboFlow-LC-MS/MS in urine from Danish children and adolescents. International Journal of Hygiene and Environmental Health 2017220 244-253. (https://doi. org/10.1016/j.ijheh.2016.08.005)

26 Middleton DR, Watts MJ, Lark RM, Milne CJ \& Polya DA. Assessing urinary flow rate, creatinine, osmolality and other hydration adjustment methods for urinary biomonitoring using NHANES arsenic, iodine, lead and cadmium data. Environmental Health 2016 15 68. (https://doi.org/10.1186/s12940-016-0152-x)

27 Chellakooty M, Vangsgaard K, Larsen T, Scheike T, Falck-Larsen J, Legarth J, Andersson AM, Main KM, Skakkebaek NE \& Juul A. A longitudinal study of intrauterine growth and the placental growth hormone $(\mathrm{GH})$-insulin-like growth factor I axis in maternal circulation: association between placental GH and fetal growth. Journal of Clinical Endocrinology and Metabolism 200489 384-391. (https://doi.org/10.1210/jc.2003-030282)

28 Lacroix MC, Guibourdenche J, Frendo JL, Muller F \& Evain-Brion D. Human placental growth hormone - a review. Placenta 200223 (Supplement A) S87-S94. (https://doi.org/10.1053/plac.2002.0811)

29 Chellakooty M, Skibsted L, Skouby SO, Andersson AM, Petersen JH, Main KM, Skakkebaek NE \& Juul A. Longitudinal study of serum placental GH in 455 normal pregnancies: correlation to gestational age, fetal gender, and weight. Journal of Clinical Endocrinology and Metabolism 200287 2734-2739. (https://doi.org/10.1210/ jcem.87.6.8544)

30 Coutant R, de Boux CF, Douay O, Mathieu E, Rouleau S, Beringue F, Gillard P, Limal JM \& Descamps P. Relationships between placental GH concentration and maternal smoking, newborn gender, and maternal leptin: possible implications for birth weight. Journal of Clinical Endocrinology and Metabolism 200186 4854-4859. (https:// doi.org/10.1210/jcem.86.10.7971)

31 Tinggaard J, Aksglaede L, Sorensen K, Mouritsen A, Wohlfahrt-Veje C, Hagen CP, Mieritz MG, Jørgensen N, Wolthers OD, Heuck C, et al. The 2014 Danish references from birth to 20 years for height, weight and body mass index. Acta Paediatrica 2014103 214-224. (https:// doi.org/10.1111/apa.12468)

32 Kramer MS. Determinants of low birth weight: methodological assessment and meta-analysis. Bulletin of the World Health Organization 198765 663-737.

33 Holst KK \& Budtz-Joergensen E. Linear latent variable models: the lava-package. Computational Statistics 201328 1385-1452. (https:// doi.org/10.1007/s00180-012-0344-y)

34 R Development Core Team. $R$ : A language and environment for statistical computing. Version 3.3.2. Vienna, Austria: R Foundation for Statistical Computing, 2008. (available at: http://www.R-project.org)

35 Lagarde F, Beausoleil C, Belcher SM, Belzunces LP, Emond C, Guerbet M \& Rousselle C. Non-monotonic dose-response relationships and endocrine disruptors: a qualitative method of assessment. Environmental Health 201514 13. (https://doi. org/10.1186/1476-069X-14-13)

36 Vandenberg LN, Colborn T, Hayes TB, Heindel JJ, Jacobs DR Jr, Lee DH, Shioda T, Soto AM, vom Saal FS, Welshons WV, et al. Hormones and endocrine-disrupting chemicals: low-dose effects and nonmonotonic dose responses. Endocrine Reviews 201233 378-455. (https://doi.org/10.1210/er.2011-1050)

37 Forhead AJ \& Fowden AL. Thyroid hormones in fetal growth and prepartum maturation. Journal of Endocrinology 2014221 R87-R103. (https://doi.org/10.1530/JOE-14-0025)

38 Caufriez A, Frankenne F, Hennen G \& Copinschi G. Regulation of maternal IGF-I by placental GH in normal and abnormal human pregnancies. American Journal of Physiology 1993265 E572-E577.

39 Delmis J, Drazancic A, Ivanisevic M \& Suchanek E. Glucose, insulin, HGH and IGF-I levels in maternal serum, amniotic fluid and umbilical venous serum: a comparison between late normal pregnancy and pregnancies complicated with diabetes and fetal growth retardation. Journal of Perinatal Medicine 199220 47-56. (https://doi.org/10.1515/jpme.1992.20.1.47)

40 Lauszus FF, Klebe JG \& Flyvbjerg A. Macrosomia associated with maternal serum insulin-like growth factor-I and -II in diabetic pregnancy. Obstetrics and Gynecology 200197 734-741.

41 Olausson H, Lof M, Brismar K, Forsum E \& Sohlstrom A. Maternal serum concentrations of insulin-like growth factor (IGF)-I and IGF binding protein-1 before and during pregnancy in relation to maternal body weight and composition and infant birth weight. British Journal of Nutrition 2010104 842-848. (https://doi. org/10.1017/S0007114510001224)

42 Chan S, Kachilele S, McCabe CJ, Tannahill LA, Boelaert K, Gittoes NJ, Visser TJ, Franklyn JA \& Kilby MD. Early expression of thyroid hormone deiodinases and receptors in human fetal cerebral cortex. Brain Research: Developmental Brain Research 2002138 109-116. (https://doi.org/10.1016/S0165-3806(02)00459-5)

43 Iskaros J, Pickard M, Evans I, Sinha A, Hardiman P \& Ekins R. Thyroid hormone receptor gene expression in first trimester human fetal brain. Journal of Clinical Endocrinology and Metabolism 200085 2620-2623. (https://doi.org/10.1210/jcem.85.7.6766)

44 Feldt-Rasmussen U \& Mathiesen ER. Endocrine disorders in pregnancy: physiological and hormonal aspects of pregnancy. Best Practice and Research Clinical Endocrinology and Metabolism 201125 875-884. (https://doi.org/10.1016/j.beem.2011.07.004)

45 Calvo RM, Jauniaux E, Gulbis B, Asuncion M, Gervy C, Contempre B \& Morreale de Escobar G. Fetal tissues are exposed to biologically relevant free thyroxine concentrations during early phases of development. Journal of Clinical Endocrinology and Metabolism 2002 87 1768-1777. (https://doi.org/10.1210/jcem.87.4.8434)

46 Henrichs J, Bongers-Schokking JJ, Schenk JJ, Ghassabian A, Schmidt HG, Visser TJ, Hooijkaas H, de Muinck KeizerSchrama SM, Hofman A, Jaddoe VV, et al. Maternal thyroid function during early pregnancy and cognitive functioning in early childhood: the generation R study. Journal of Clinical Endocrinology and Metabolism 201095 4227-4234. (https://doi. org/10.1210/jc.2010-0415)

47 Leon G, Murcia M, Rebagliato M, Alvarez-Pedrerol M, Castilla AM, Basterrechea M, Iñiguez C, Fernández-Somoano A, Blarduni E, Foradada CM, et al. Maternal thyroid dysfunction during gestation, preterm delivery, and birthweight. The Infancia y Medio Ambiente Cohort, Spain. Paediatric and Perinatal Epidemiology 201529 113-122. (https://doi.org/10.1111/ppe.12172)

48 Millar LK, Wing DA, Leung AS, Koonings PP, Montoro MN \& Mestman JH. Low birth weight and preeclampsia in pregnancies complicated by hyperthyroidism. Obstetrics and Gynecology 199484 946-949.

49 Lonberg U, Damm P, Andersson AM, Main KM, Chellakooty M, Lauenborg J, Skakkebaek NE \& Juul A. Increase in maternal placental growth hormone during pregnancy and disappearance during parturition in normal and growth hormone-deficient pregnancies. American Journal of Obstetrics and Gynecology 2003188 247-251. (https://doi.org/10.1067/mob.2003.82)

50 Kedzia A, Petriczko E \& Tarka A. Placental growth hormone, pituitary growth hormone, insulin-like growth factor, and ghrelin in umbilical cord blood serum and amniotic fluid. Endokrynologia Polska 201364 293-299. (https://doi.org/10.5603/EP.2013.0008)

51 Baumann MU, Schneider H, Malek A, Palta V, Surbek DV, Sager R, Zamudio S \& Illsley NP. Regulation of human trophoblast GLUT1 glucose transporter by insulin-like growth factor I (IGF-I). PLOS ONE 20149 e106037. (https://doi.org/10.1371/journal.pone.0106037)

52 Handwerger S \& Freemark M. The roles of placental growth hormone and placental lactogen in the regulation of human fetal growth and development. Journal of Pediatric Endocrinology and Metabolism 2000 13 343-356. 
53 Jones HN, Powell TL \& Jansson T. Regulation of placental nutrient transport - a review. Placenta 200728 763-774. (https://doi. org/10.1016/j.placenta.2007.05.002)

54 Karl PI. Insulin-like growth factor- 1 stimulates amino acid uptake by the cultured human placental trophoblast. Journal of Cellular Physiology 1995165 83-88. (https://doi.org/10.1002/jcp.1041650111)

55 Jeon HK, Sarma SN, Kim YJ \& Ryu JC. Toxicokinetics and metabolisms of benzophenone-type UV filters in rats. Toxicology 2008 248 89-95. (https://doi.org/10.1016/j.tox.2008.02.009)

56 Nakagawa Y \& Tayama K. Benzophenone-induced estrogenic potency in ovariectomized rats. Archives of Toxicology 200276 727-731. (https://doi.org/10.1007/s00204-002-0401-3)

57 Koch HM, Aylward LL, Hays SM, Smolders R, Moos RK, Cocker J, Jones K, Warren N, Levy L \& Bevan R. Inter- and intra-individual variation in urinary biomarker concentrations over a 6-day sampling period. Part 2: personal care product ingredients. Toxicology Letters 2014231 261-269. (https://doi.org/10.1016/j.toxlet.2014.06.023)

58 Meeker JD, Cantonwine DE, Rivera-Gonzalez LO, Ferguson KK, Mukherjee B, Calafat AM, Ye X, Anzalota Del Toro LV, CrespoHernández N, Jiménez-Vélez B, et al. Distribution, variability, and predictors of urinary concentrations of phenols and parabens among pregnant women in Puerto Rico. Environmental Science and Technology 201347 3439-3447. (https://doi.org/10.1021/es400510g)

59 Teitelbaum SL, Britton JA, Calafat AM, Ye X, Silva MJ, Reidy JA, Galvez MP, Brenner BL \& Wolff MS. Temporal variability in urinary concentrations of phthalate metabolites, phytoestrogens and phenols among minority children in the United States. Environmental Research 2008106 257-269. (https://doi.org/10.1016/j.envres.2007.09.010)

60 Dewalque L, Pirard C, Vandepaer S \& Charlier C. Temporal variability of urinary concentrations of phthalate metabolites, parabens and benzophenone-3 in a Belgian adult population. Environmental Research 2015142 414-423. (https://doi.org/10.1016/j. envres.2015.07.015)

61 Lassen TH, Frederiksen H, Jensen TK, Petersen JH, Main KM, Skakkebaek NE, Jørgensen N, Kranich SK \& Andersson AM. Temporal variability in urinary excretion of bisphenol A and seven other phenols in spot, morning, and 24-h urine samples. Environmental Research 2013 126 164-170. (https://doi.org/10.1016/j.envres.2013.07.001)

62 Welsh KJ \& Soldin SJ. Diagnosis of endocrine disease: how reliable are free thyroid and total T3 hormone assays? European Journal of Endocrinology 2016175 R255-R263. (https://doi.org/10.1530/EJE16-0193)
Received in final form 17 January 2018

Accepted 23 January 2018

Accepted Preprint published online 23 January 2018 http://www.endocrineconnections.org https://doi.org/10.1530/EC-17-0375
C) 2018 The authors Published by Bioscientifica Ltd International License. 